\title{
CLINOCO-PATHOLOGICAL CORRELATION IN TREATED WHIPPLE'S DISEASE
}

\author{
LIEUTENANT-COLONEL D. M. ROBERTS, M.D., F.R.C.P.(Ed.), R.A.M.C. \\ Royal Army Medical College, Millbank \\ LIEUTENANT-COLONEL J. R. DONALDSON, \\ M.B., Ch.B., M.R.C.Path, D.R.C.Path., Dip.Bact., R.A.M.C. \\ Cambridge Military Hospital, Aldershot
}

IN 1907, at the Johns Hopkins Hospital, an autopsy was performed by Whipple on a doctor colleague who had died following a protracted wasting illness. As a result he published the first account of the disease which bears his name (Whipple 1907). It is an uncommon disorder characterised by diarrhoea, streatorrhea, loss of weight, anaemia, arthralgia and skin pigmentation. Whipple described an intense accumulation of fat within the intestinal mucosa and coined the descriptive name 'intestinal lipodystrophy'.

Black-Schaffer (1949), using light microscopy, first demonstrated within the mucosa of the small intestine an intense infiltration with macrophages containing granules which stain strongly by the periodic acid-Schiff (PAS) method.

Within recent years, the bacterial aetiology of this disease has been established beyond reasonable doubt, mainly by the application of electron microscope techniques to jejunal biopsy specimens.

Without treatment the illness is usually fatal within two years. Recently antibiotic therapy has proved very effective and its success has provided additional support for a bacterial aetiology of the disease. However, few reports have correlated clinical, biochemical, histological and ultrastructural progress in antibiotictreated patients. This paper presents such a correlation in two patients.

\section{Case histories}

Case 1.

Male aged 34 years. Three and a half years ago he started having attacks of pain in both hands and ankles, followed by pain in the back and the left shoulder. Because of dyspeptic symptoms cholecystogram and barium meal were undertaken but both were normal, although hypochlorhydria was demonstrated. A year later skin pigmentation appeared and thereafter steadily increased. Diarrhoea, with up to 10 stools daily, started 6 months ago and was accompanied by cachexia. At presentation body weight was $53.0 \mathrm{~kg}$.

\section{Case 2.}

Male aged 40 years (Fig. 1). For seven years this patient suffered attacks of pain in the hands and feet, mainly during the winter, but this ceased two years ago. Eight years ago he started having attacks of fever lasting for a day or two and 


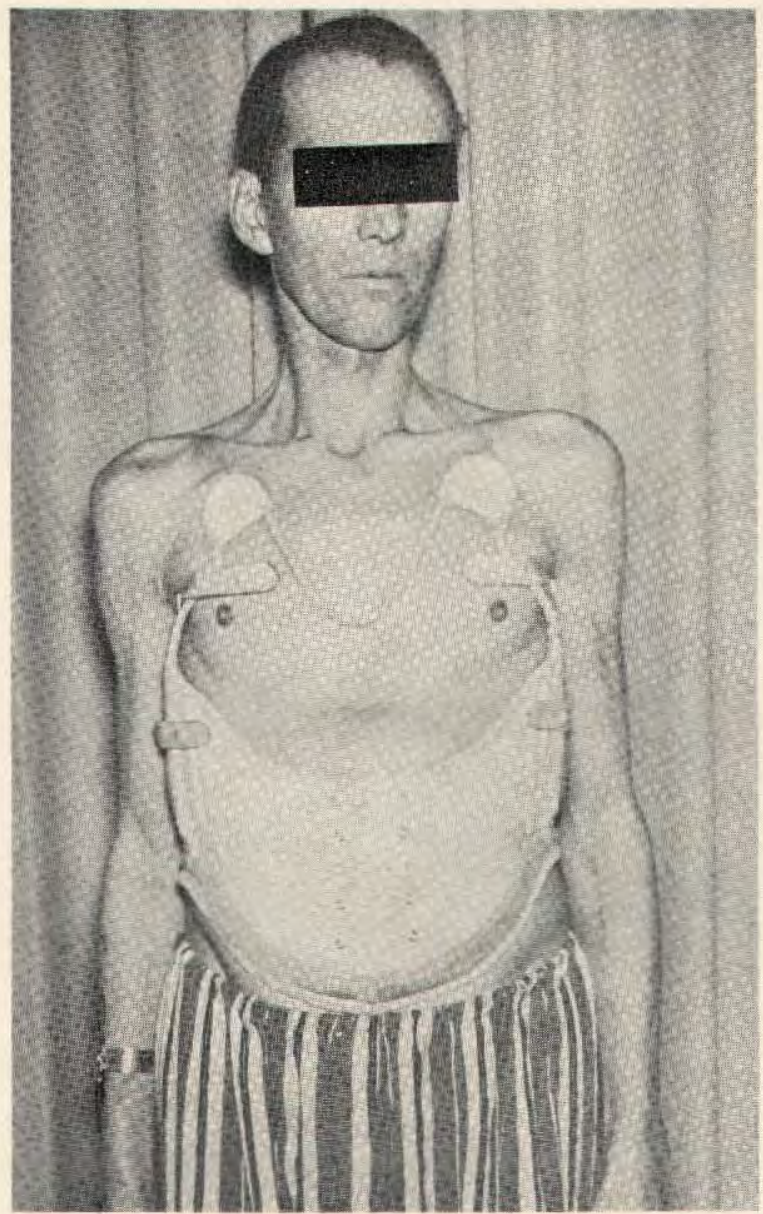

Fig. 1. Case 2. Male aged 40 years. Weight $53.1 \mathrm{~kg}$. The patient is wearing an appliance providing spinal support because of a spontaneous fracture of the body of the first lumbar vertebra.

occurring every few days or weeks. Six years ago he was treated with tetracycline $250 \mathrm{mg}$ four times daily for 10 days for a presumed, but undiscovered, 'septic focus' and this resulted in cessation of fever. Onset of diarrhoea, with three or four stools daily occurred two years ago, and was only partially ameliorated by a 7-day course of chloramphenicol $250 \mathrm{mg}$ four times daily and a gluten-free diet for one month. Cachexia was severe, and at presentation his weight was $53.1 \mathrm{~kg}$. At that time there was considerable peripheral oedema due to hypoalbuminaemia, and he was found to have a spontaneous fracture of the body of the first lumbar vertebra.

\section{Results}

The results of some investigations of the two patients with Whipple's disease are shown in Table I, and the treatment given, together with clinical response is shown below. 
Table I

Features of two patients with Whipple's disease

\begin{tabular}{|c|c|c|}
\hline Investigations & Case 1 & Case 2 \\
\hline Haemoglobin & $10.2 \mathrm{~g} / \mathrm{dl}$ & $5.8 \mathrm{~g} / \mathrm{dl}$ \\
\hline $\begin{array}{l}\text { Mean corpuscular haemoglobin } \\
\text { concentration }\end{array}$ & - & 25 per cent \\
\hline Serum iron & $6.6_{\mu} \mathrm{mol} / 1$ & $5.9_{\mu} \mathrm{mol} / 1$ \\
\hline Serum folate & $5.2 \mathrm{ng} / \mathrm{ml}$ & more than $32 \mathrm{ng} / \mathrm{ml}$ \\
\hline Serum vitamin $\mathrm{B} 12$ & $725 \mathrm{pg} / \mathrm{ml}$ & $740 \mathrm{pg} / \mathrm{ml}$ \\
\hline Faecal fat & $18.2 \mathrm{~g} /$ day & $28.5 \mathrm{~g} /$ day \\
\hline $\begin{aligned} \text { Serum proteins: } & \text { Total } \\
& \text { Albumin }\end{aligned}$ & $\overline{-}$ & $\begin{array}{l}43 \mathrm{~g} / 1 \\
19 \mathrm{~g} / 1\end{array}$ \\
\hline Serum cholesterol & - & $2.4 \mathrm{mmol} / 1$ \\
\hline Total blood lipids & 一 & $1.9 \mathrm{~g} / 1$ \\
\hline D-xylose excretion & - & 26 per cent \\
\hline Urinary indican & - & less than $5 \mathrm{mg} / 24 \mathrm{hr}$ \\
\hline Schilling test & - & Normal B12 absorption \\
\hline $\begin{array}{l}\text { Barium X-rays of small in- } \\
\text { testine }\end{array}$ & 'Malabsorption pattern' & 一 \\
\hline Bone X-rays & - & $\begin{array}{l}\text { Marked generalised oesteopor- } \\
\text { osis with fractured body of } \\
\text { first lumbar vertebra }\end{array}$ \\
\hline Jejunal biopsy & $\begin{array}{l}\text { 1. } \\
\text { 2. (18 days after biopsy } 1) \\
\text { 3. (28 days after biopsy } 2) \\
\end{array}$ & 2. (50 days after biopsy 1$)$ \\
\hline Inguinal lymph node biopsy & - & $\begin{array}{l}\text { Taken } 16 \text { days after jejunal } \\
\text { biopsy } 1\end{array}$ \\
\hline
\end{tabular}

\section{Treatment}

Case 1. Starting immediately after second jejunal biopsy: 1. Chloramphenicol $2 \mathrm{~g}$ daily for 14 days, followed by $1.5 \mathrm{~g}$ daily for 3 months. 2 . High-protein, low-fat diet. 3 . Steroid therapy for 23 days when the weight gain faltered.

Case 2. Starting the day after the first jejunal biopsy: 1. Ampicillin $1.5 \mathrm{~g}$ daily for 6 months. 2 . High-protein, low-fat diet.

\section{Clinical response}

Case 1. Return of stools to normal within 17 days. Weight gain of $17 \mathrm{~kg}$ within 45 days. Resolution of anaemia. Remained well 3 months after discontinuation of treatment.

Case 2. Return of stools to normal within 2 days. Subsidence of oedema within 3 weeks, at which time body weight was $54.5 \mathrm{~kg}$.

The histological and ultrastructural findings in jejunal biopsies taken before and after treatment are summarized. 


\section{Before treatment}

Jejunal biopsy

Light microscopy (Fig. 2). Lymphocytes present within epithelium. Lamina propria densely packed with macrophages which contain PAS-positive granules. Large round globules, possible containing lipid material, in extracellular space of lamina propria.

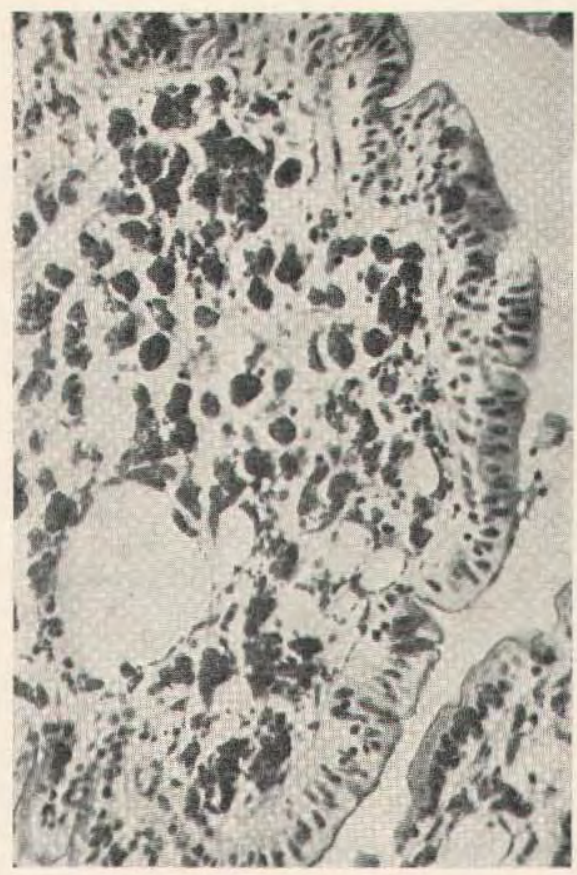

Fig. 2. Jejunal mucosa from Case 2. Before treatment. Lamina propria densely packed with macrophages which contain PAS-positive granules. PAS $\times 1800$.

Electron microscopy (Fig. 3). Bacterioid inclusions in 'heterophagic vacuoles' within epithelial cells. Extracellular bacteria throughout lamina propria, in highest concentration just below basement membrane. Lamina propria packed with macrophages which contain ingested bacteria in various stages of disintegration. Degeneration takes place in 'heterophagic vacuoles' which correspond to PAS-positive granules in light microscopy. 'Lipid' droplets seen both within macrophages and in extracellular space.

\section{Lymph node biopsy}

Electron microscopy. Macrophages similar to those found in the jejunal mucosa.

\section{After treatment}

\section{Jejunal biopsy}

Light microscopy. Generally, a marked return to normal, with reduction of numbers of macrophages and decreased prominence of granules. 


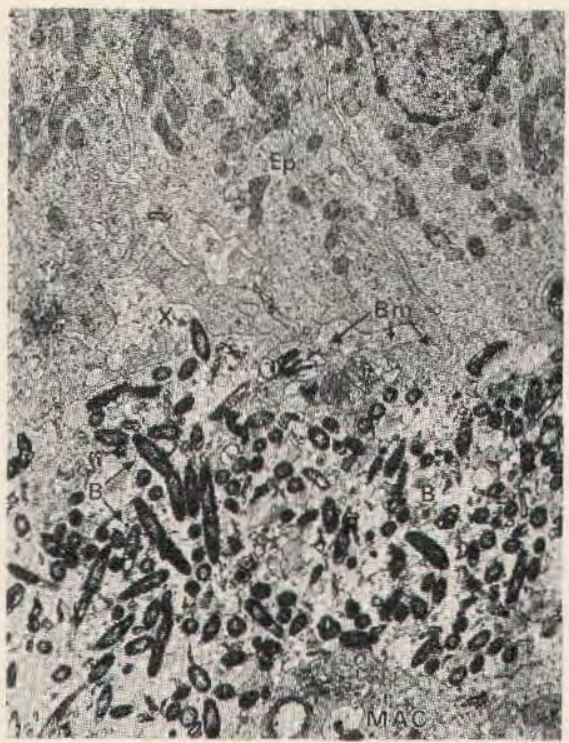

Fig. 3. Jejunal mucosa from Case 2. Before treatment. Many bacteria (B) just below the basement membrane $(\mathrm{Bm})$, and one bacterium passing through an opening in it (X). Ep=Epithelium; MAC $=$ Macrophages. $\mathrm{EM} \times 16,000$.

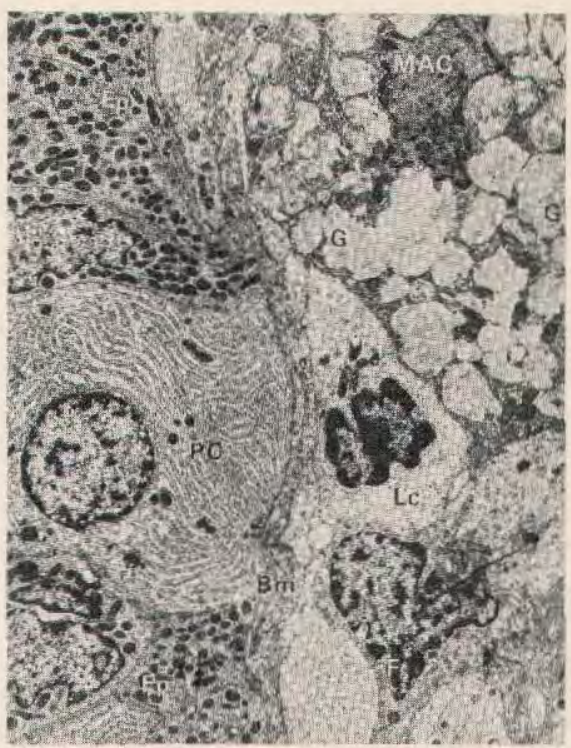

Fig. 4. Jejunal mucosa from Case 2. After treatment. Absence of bacteria. $\mathrm{Ep}=$ Epithelium; $\mathrm{PC}=$ basal part of a Paneth cell; $\mathrm{Bm}=$ subepithelial basement membrane. $\mathrm{MAC}=$ Macrophages; $\mathrm{G}=$ heterophagic vacuoles; $\mathrm{Lc}=\mathrm{Lympho-}$ cyte; $\mathrm{F}=$ nucleus of a fibrocyte. $\mathbf{E M} \times$ 9,000 .

Electron microscopy (Fig. 4). Bacteria no longer present. Macrophages still present in large numbers, but now also many lymphocytes and plasma cells seen. Macrophages contain vacuoles with amorphous or membranous content, derived from bacterial cell-wall.

\section{Discussion}

Early concepts of the pathogenesis of Whipple's disease centred around a defect in lipid metabolism (Reinhart and Wilson 1939, Pearse 1942, Apperly and Copley 1943, Rosen and Rosen 1947). With the application of PAS stain to biopsies from Whipple's disease, speculation turned to abnormalities of carbohydrate and protein metabolism (Haubrich, Watson and Sieracki 1960, Fisher 1962, Upton 1952). Within the past 12 years these theories, and several others (Hollenberg 1962), have been swept away by the finding under the electron microscope of bacteria within the mucosa of the small intestine (Cohen et al 1960, Chears and Ashworth 1961, Trier et al 1963).

The question of whether these bacteria are of primary aetiological significance has not been finally resolved. However, it seems likely that they are, since they are never seen in control biopsies. They are of identical ultrastructural appearance in all reports to date, and there is a favourable clinical response to antibiotics (Trier and Phelps 1963). Primary bacterial aetiology is also supported by the cellular reaction with phagocytosis by macrophages, and current opinion is that the PASpositive material within the macrophages is derived from bacilli and their residues. 
In Munster, we were able to confirm this observation, and we have proposed a sequential degradation process for bacteria within macrophages which would account for all the different types of ultrastructural lesions seen (Themann et al 1969, Roberts et al 1970).

The missing link, however, is the failure of most attempts to date to culture an organism from the lesion in the small intestine. There have been reports of isolation of anaerobic diphtheriods (Kent et al 1963), and of a haemophilus (Kok, Dybkaer and Rostgaard 1964), but there is no confidence that these have not been contaminants. A particularly strenuous attempt at culture of an organism by Sherris, Roberts and Porus (1965) failed. We were able to isolate, in almost pure culture, an $\alpha$-haemolytic streptococcus whose initial morphology was more bacillary than coccal and which, on first isolation, had more gram-negative cells than on subsequent subculture, when it also showed a great increase in chain length. This is in keeping with the proposed sequential degradation process and it would be reasonable to expect isolation on ordinary media of an organism which is of normal structure while still within the gut lumen. The isolate was confirmed as a group $\mathrm{O}$ Streptococcus (Boissard and Wormald 1950) by Dr. M. T. Parker. It is a normal mouth and throat inhabitant in some individuals and is thought to equate to some strains of Streptococcus mitis. It was recoverable from one of six suckling mice inoculated intracerebrally with jejunal biopsy material. Nevertheless, it was not possible to prove that this organism was not a luminal contaminent, and these findings are unpublished. It is of interest to note that antibiotics which act to prevent murein synthesis, such as the penicillins, may be effective in therapy, further supporting the concept of sequential degradation in an organism which may be normally resident in the gut lumen. Clancy et al (1975) have recently reported growth of a cell wall deficient form of an $\alpha$-haemolytic streptococcus from a prolonged monolayer cell culture of a lymph node taken from a patient with Whipple's disease. On biochemical criteria the organism was identified as Streptococcus dysgalactiae. Serological cross-reactivity was shown between the organism and PASpositive material within Whipple's macrophages. Cell wall deficient forms of streptococci have been isolated from patients with Whipple's disease on two other occasions (Knox et al 1968, Charache et al (1966)) but with less certainty about their significance.

The rarity of the disease suggests either that the infecting organism may be an unusual rather than a ubiquitous one or, alternatively, that host immunodeficiency is the vital aetiological factor. The latter would explain how an organism of low antigenicity could exist for long periods intra-cellularly in certain tissues. The paucity of plasma cells within the mucosa and the peculiar proliferation of macrophages suggested to Dobbins and Ruffin (1967) that a disorder of immune tolerance may be involved. The organism is not confined to the intestinal mucosa or lymph nodes since it has also been reported to be present in pericardium (Chears and Ashworth 1961) and heart valves (Forbus, cited by Dobbins and Ruffin 1967). However, the intestinal mucosa undoubtedly bears by far the heaviest infection and this suggests that any immunological defect may be tissue-specific.

The clinical features of our two patients on presentation can all be explained on the basis of intestinal malabsorption and, perhaps, protein-losing enteropathy, 
although the latter was not established. The unusually high serum folate in case 2 might conceivably have arisen from bacterial proliferation within the intestine. The manifest bacterial invasion of the intestinal mucosa and the host response thereto is shown to resolve in the face of antibiotic therapy, and this parallels the remarkable clinical response. The duration of antibiotic therapy needed to establish a permanent cure, if indeed this is possible, has yet to be established (Trier et al 1965, Oliva et al 1972). The suggestion, by Clancy et al (1975), that complete return to normal of $\mathrm{T}$-lymphocyte numbers and function occurs following antibiotic therapy raises the question of the possibility of use of transfer factor in these patients.

\section{Acknowledgement}

We are grateful to Professor $H$. Themann of Munster University for the electronmicrographs.

\section{REFERENCES}

APPERLY, F. L. and Copley, E. L. (1943). Gastroenterology 1, 461. Black-SChaffer, B. (1949). Proc. Soc. exp. Biol. (N.Y.) 72, 225.

Boissard, J. M. and Wormald, P. J. (1950). J. Path. Bact. 62, 37.

Chears, W. C. Jr., and Ashworth, C. T. (1961). Gastroenterology 41, 129.

Charache, P., Bayless, T. M., Shelley, W. M. and Hendrix, T. R. (1966). Trans. Ass. Amer. Phycns. 79, 399.

Clancy, R. L., Tomkins, W. A. F., Muckle, T. J., Richardson, H. and RaWls, W. E. (1975). Brit. med. J. iii, 568.

Cohen, A. S., Schimmel, E. M., Holt, P. R. and Isselbacher, K. J. (1960). Proc. Soc. exp. Biol. (N.Y.) 105, 411 .

Dobiins, W. O. III, and Ruffin, J. M. (1967). Amer. J. Path. 51, 225.

FISHER, E. R. (1962). J. Amer. med. Ass. 181, 396.

HaUbrich, W. S., Watson, J. H. L., and SieraCki, J. C. (1960). Gastroenterology 39, 454.

Hollenberg, M. (1962), Amer. J. Med. 32, 448.

Kent, T. H., Layton, J. M., Clifton, J. A. and Schedl, H. P. (1963). Lab. Invest. 12, 1163.

KoK, N., DYBKaER, R. and RostgaARD, J. (1964). Act. path. microbiol. scand. 60, 431.

KnoX, D. L., Bayless, T. M., Yardley, J. H. and Charache, P. (1968). Johns Hopk. med. J. 123,175 .

Oliva, H., Gonzalea Campos, C., Nayarro, V. and Mogena, H. H. (1972). Gut 13, 430. Pearse, H. E. (1942). Surgery 11, 906.

Reinhart, H. L. and Wilson, S. J. (1939). Amer. J. Path. 15, 483.

Roberts, D. M., Themann, H., Knust, F-J., Preston, F. E. and Donaldson, J. R. (1970). J. Path. 100, 249.

Rosen, M. S. and Rosen, S. H. (1947). Amer. J. Path. 23, 443.

Sherris, J. C., Roberts; C. E. and Porus, R. L. (1965). Gastroenterology 48, 708.

Themann, H., Roberts, D. M., Knust, F-J. and Schmidt, E. (1969). Beitr. path. Anat. 139, 12.

Trier, J. S. and Phelps, P. C. (1963). J. Lab. clin. Med. 62, 1017.

Trier, J. S., Phelps, P. C., Eidelman, S. and Rubin, C. E. (1963). J. Amer. med. Ass. 183, 768.

Trier, J. S., Phelps, P. C., Eidelman, S. and Rubin, C. E. (1965). Gastroenterology 48, 684. UPTON, A. C. (1952). Amer. J. clin. Path. 22, 755.

WhIPPLE, G. H. (1907). Bull. Johns. Hopk. Hosp. 18, 382. 